\title{
PERIARTICULAR CALCIFICATION IN PARAPLEGICS: ATTEMPTED TREATMENT WITH DISODIUM EDETATE*
}

\author{
Sedgwick Mead, M.D., Harvey D. Cain, M.D., Robert E. Kelly, M.D., \\ and HowARD LiEBgold, M.D. \\ From the Kaiser Foundation Rehabilitation Center, Vallejo, California, U.S.A.
}

\section{INTRODUCTION}

A MAJOR deterrent to the rehabilitation of patients with paraplegia is the severe joint limitation resulting from periarticular accumulation of heterotopic bone that occurs in approximately 28 per cent. (Damanski, 196I) to 48 per cent. (Déjerine \& Ceillier, I918) of persons so disabled. The extra-articular deposition of heterotopic bone in paraplegia and other neurological disorders was first described by Déjerine and Ceillier in 1918. Despite extensive clinical investigation during the ensuing four decades, its cause remains obscure and an effective therapeutic tool has not been found. Certain observations that were made during our attempt to resolve such calcification with disodium edetate raise interesting points of inquiry.

\section{THE THERAPEUTIC PROBLEM}

Heterotopic bone has been most recently defined by Damanski (I96I) as the formation of new bone in the vicinity of an unchanged joint. It is always both extracapsular and extra-articular. It is most commonly found about the hips and knees, but has been reported in shoulders, elbows, and wrists and even in the small joints of the hands. It does not occur above the level of the lesion and has not been reported below the knee. Histologically the deposits are revealed to be modified true bone, complete with Haversian systems, osteoblasts, and bone marrow.

Heterotopic bone is associated with central nervous system damage, most commonly with lesions of the cervical cord and less frequently with incomplete cord lesions. It has been recorded in conjunction with poliomyelitis, multiple sclerosis, and occasionally with hemiplegia, as well as in traumatic myelopathy. In one of our cases the primary disorder was spastic parapelgia resulting from bilateral trauma to the brain.

The periarticular calcification appears early in the spinal cord affection, usually between the sixth and tenth week, and is generally progressive through the first year. It has often been correlated with urinary tract infections, pressure sores, absence of or too vigorous application of passive physical therapy, loss of joint position sense, local osteoporosis, local haematoma, or changes in the sympathetic nervous system. Many cases have been recorded, however, in which none of these complications existed at the time the ectopic bone developed.

The concept that the extra-articular bone formation is initiated by the occurrence of local supersaturated solutions of calcium and phosphorus is untenable in the light of the fact that all body solutions are inconstantly metastable with July 1962 .

* Read at the Scientific Meeting of the International Medical Society of Paraplegia. 
regard to calcium and phosphorus, and that all native collagen is capable of initiating ossification. Metabolic studies of patients with paraplegia have likewise failed to reveal a cause for the phenomenon. The metabolic changes that are observed are similar to, although often more severe than, those seen in association with severe trauma, starvation, imposed bed rest, severe infection-conditions in which heterotopic bone formation has not been reported.

Attempts to treat the disorder caused by heterotopic bone have included the use of corticoids, diathermy, roentgenotherapy, ultrasound, and diet. None of these agents has altered the existing deposits or has prevented continued deposition. Surgical intervention has met with a high infection rate and frequently with recurrence, which has often necessitated disarticulation of the hip.

In our search for a useful therapeutic tool three patients were treated with disodium edetate. All had extensive calcification about the hip joints and upper portion of the femurs, resulting in severe limitation of motion.

\section{THEORETICAL BASIS FOR THE USE OF DISODIUM EDETATE}

Calcium disodium ethylenediamine tetra-acetic acid (edetate, formerly edathamil; EDTA), a chelating agent, has long been used to remove from the body toxic heavy ions such as lead. The disodium salt without calcium (disodium edetate) can be used similarly to mobilize abnormal calcium deposits (Clarke et al., 1955). Toxic nephropathy results unless the dose is held to or below $50 \mathrm{mg}$. per kilogram of body weight (Dudley et al., I955; Foreman et al., 1956). The drug is usually administered intravenously, the above dose in a suitable diluent running in slowly over four to eight hours.

Procedure. Preceding the therapeutic trial of disodium edetate in the three patients, roentgenograms of the hips and upper portion of the femurs were obtained, together with goniometry. Kidney function studies (routine urine analysis, excretory urography, and estimation of serum blood urea nitrogen) ruled out severe pre-existing pyelonephritis and excluded the likelihood of hyperparathyroidism secondary to renal disease. Liver function was estimated by means of the Bromsulphalein test, and by measurements of the fractional serum protein and serum bilirubin. A two-hour glucose tolerance test was carried out. Levels of serum calcium, phosphorus, and alkaline phosphatase were determined. The erythrocyte sedimentation rate was obtained.

For one week prior to the I9-day therapeutic trial, and during it, each of the three patients received a standardised diet containing approximately $310 \mathrm{mg}$. of calcium and $1000 \mathrm{mg}$. of phosphorus. Disodium edetate was given in dosage of $50 \mathrm{mg}$. per kilogram of body weight during three 5-day periods with 2-day rest periods between. Each dose of the drug was dissolved in $1000 \mathrm{ml}$. of 5 per cent. glucose in sterile distilled water, and allowed to run into the vein at a rate of approximately $1000 \mathrm{ml}$. in eight hours. The intravenous infusions were given at night so as not to interfere with the physical therapy schedule. The preparation is irritating to the endothelium, and resulted in some local venous thrombosesthe only observed side-effects.

During the I9 days of treatment the urine was tested frequently by the Solkowitsch method and the total 24-hour urinary excretion of calcium and phosphorus was estimated, not daily but at random intervals. Values reported 
are averages of samples measured. No attempt was made to estimate the fecal calcium excretion.

At the end of the study roentgenography and goniometry were repeated, as were determinations of serum levels of calcium, phosphorus, and alkaline phosphatase, and study of urinary protein and sediment.

Results. Solkowitsch tests before and after treatment revealed normal turbidity of the urine; during treatment, with few exceptions, the turbidity was markedly or moderately increased. Results of two-hour glucose tolerance tests serum bilirubin levels, bromsulphalein retention tests, and corrected erythrocyte sedimentation rates were normal in each case.

Case r. The patient was a 22-year-old man with spastic paraplegia from bilateral trauma to the brain, of seven months' duration. Disodium odetate was given in dosage of $2.7 \mathrm{~g}$. daily for the 15 days of intravenous infusions.

Prior to treatment with disodium edetate the urinary specific gravity was I.0IO; the urine contained no protein or glucose, and its sediment contained no cells or casts. The 24-hour urinary calcium excretion was $54 \mathrm{mg}$.; 24-hour phosphorus excretion, $430 \mathrm{mg}$. The serum chemistry levels, per 100 millilitres, were: calcium, $9.5 \mathrm{mg}$.; phosphorus, $4.5 \mathrm{mg}$.; alkaline phosphatase, 9.4 (Bodansky units); blood urea nitrogen, I 4.5 mg.; albumin, 3.5 g.; globulin, 3.3 g.; potassium, $4.5 \mathrm{mEq}$. per litre.

During treatment, the average volume of five 24 -hour urine samples was I.IIO ml.; the average 24 -hour calcium content was $107 \mathrm{mg}$.; average 24 -hour phosphorus content, $627 \mathrm{mg}$. The average values for two 24-hour urine collections in the last week of therapy were: volume, I700 ml.; calcium, $252 \mathrm{mg}$.; phosphorus, $600 \mathrm{mg}$.

Following treatment the serum chemical determination revealed no essential change except that the alkaline phosphatase level was 5.4 Bodansky units. No change in the periarticular bone mass could be discerned by roentgenography or goniometry.

Case 2. The patient was a 24-year-old man with traumatic myelopathy resulting from a lesion of the spinal cord at the level of the third thoracic vertebra. Disodium edetate was given in dosage of $3 \mathrm{~g}$. per day for the 15 days of intravenous infusions.

Before this treatment, the urinary specific gravity was $\mathrm{I} .005$; the urine contained protein $(\mathrm{I}+)$ but no glucose; its sediment contained from IOo to I 50 white blood cells per high power field. The serum chemistry levels, per $100 \mathrm{ml}$., were: calcium, $10.6 \mathrm{mg}$.; phosphorus, $3.9 \mathrm{mg}$.; alkaline phosphatase, 19.8 and I9.6 (Bodansky units); blood urea nitrogen, $5.3 \mathrm{mg}$.; albumin, $4.2 \mathrm{~g}$.; globulin, $2.5 \mathrm{~g}$.; acid phosphatase, 0.6 (Bodansky units).

During treatment, the average volume of seven 24-hour urine samples was 2350; its average 24-hour calcium content, $370 \mathrm{mg}$; 24-hour phosphorus excretion $664 \mathrm{mg}$. The blood chemistry determinations were not repeated. Neither roentgen study nor goniometry revealed a change in the periarticular calcification.

Case 3. The patient was a 44-year-old man with traumatic myelopathy originating at the level of the seventh thoracic vertebra of eight months' duration. Disodium edetate was given in dosage of $3.0 \mathrm{~g}$., intravenously, for 15 days of infusions.

Prior to this treatment, the specific gravity of the urine was I.0I7. The urine contained protein $(\mathrm{I}+)$ but no glucose; its sediment contained no cells or casts. Expressed as averages of four specimens, the 24-hour urine volume was $3402 \mathrm{ml}$.; 24-hour calcium excretion, $243 \mathrm{mg}$.; 24 -hour phosphorus excretion, $737 \mathrm{mg}$. The serum chemistry studies revealed the following values per $100 \mathrm{ml}$.: calcium, $9.5 \mathrm{mg}$. (two determinations); phosphorus, 4.0 and $4.4 \mathrm{mg}$.; alkaline phosphatase, 13.2 and 27.7 (Bodansky units); blood urea nitrogen, $6.5 \mathrm{mg}$.; albumin, $3.5 \mathrm{~g}$.; globulin, $2.3 \mathrm{~g}$. The fasting glucose leve] was $85 \mathrm{mg}$. per I00 $\mathrm{ml}$.; the two-hour postprandial glucose level, I09 $\mathrm{mg}$. per $100 \mathrm{ml}$. 
During treatment, the average 24-hour urine volume (I6 samples over I9 days) was $3100 \mathrm{ml}$.; the 24-hour calcium excretion, I79 mg.; 24-hour phosphorus excretion, $654 \mathrm{mg}$.

Following treatment, the 24-hour urine volume was $3410 \mathrm{ml}$.; 24 -hour calcium excretion, $340 \mathrm{mg}$; 24-hour phosphorus excretion, $400 \mathrm{mg}$. Serum determinations, repeated after treatment, showed calcium, $9.5 \mathrm{mg}$. per $100 \mathrm{ml}$.; phosphorus, $3.4 \mathrm{mg}$. per I00 ml.; alkaline phosphatase, 3.4 Bodansky units. Goniometry revealed no change. The post-treatment roentgenograms, while equivocal in this respect, suggested that the degree of calcification has increased (figs. I $a-c$ ).

\section{COMMENT}

In this pilot study of treatment of periarticular calcification in three paraplegics, no demonstrable clinical improvement occurred in response to a threeweek course of therapy with full recommended doses of disodium edetate given intravenously. We were concerned about repeated courses of therapy because of the lack of clinical improvement, the time required for the treatment, and its cost, as well as possible later consequences in form of renal tubular irritation and perhaps the further demineralisation of an already demineralised skeleton.

The degree of pre-treatment elevation of alkaline phosphatase is noteworthy as we believe this has not previously been reported as an important occurrence in the periarticular calcification of myelopathy. Miller and O'Neill (I949) stated that 'studies on blood calcium, phosphorus, and phosphatase showed nothing of significance'. They did have several elevated alkaline phosphatase samples, but negated their importance. Additionally, we were interested by the degree of alkaline phosphatase levels to normal following treatment. Since the number of cases is small, we cannot comment on the significance or importance of this observation. In view of the absence of demonstrable liver disease, we feel that this decrease in alkaline phosphatase may indicate a diminution of osteoblastic activity during therapy.

The 24-hour urinary excretion of calcium by normal persons receiving a low calcium diet is in the range of 100 to $150 \mathrm{mg}$. In these patients, the observed 24-hour excretions of more than $400 \mathrm{mg}$. of urinary calcium represent a significant proportion of the approximately $1000 \mathrm{mg}$. of calcium in the normal extracellular fluid. There was no clinical or laboratory evidence of hypocalcaemia during the study; hence it is evident that rapid repletion of extracellular calcium occurs. Resorption of calcium from bone and increased alimentary absorption of calcium are probably the two main homeostatic mechanisms.

The average 24-hour urinary excretion of calcium during therapy was above normal in two of the three patients, and was above normal in the third patient also during the last week of therapy. Paradoxically, in Case 3, the average 24-hour excretion of urinary calcium was elevated above normal in both the control and the treatment collections, but was higher in the control collection.

The average 24-hour urine phosphorus excretions were within normal limits.

The importance of finding a satisfactory therapy for periarticular calcifications is obvious. We feel from our observations that a more detailed study to determine the exact metabolic course of calcium (possibly using $\mathrm{Ca}^{45}$ ) in periarticular calcifications associated with myelopathy is indicated. A clearer determination should be made of the effect of disodium edetate on mobilization of calcium in these periarticular deposits in comparison to general skeletal demineralisation. Further 
PARAPLEGIA
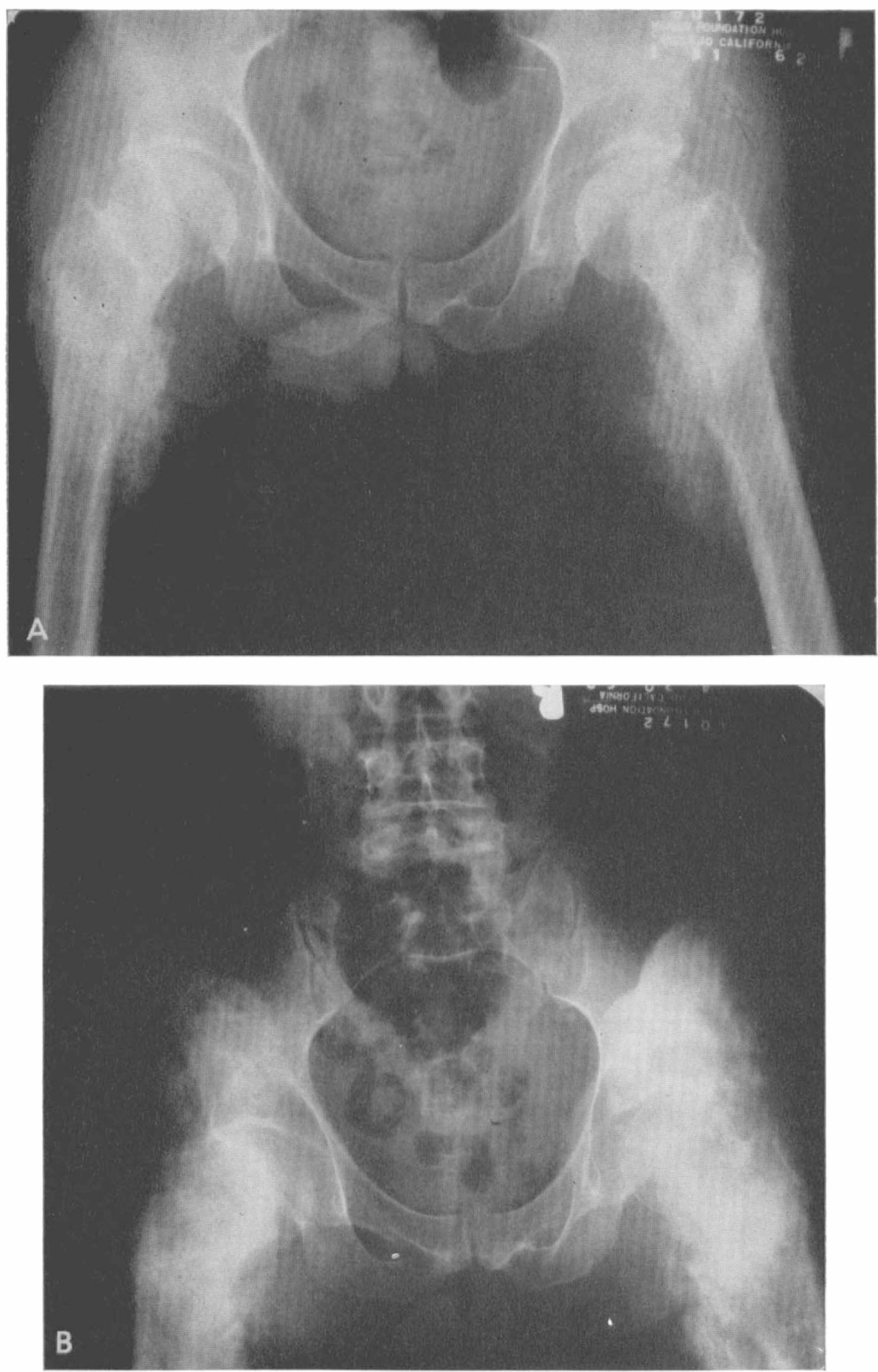


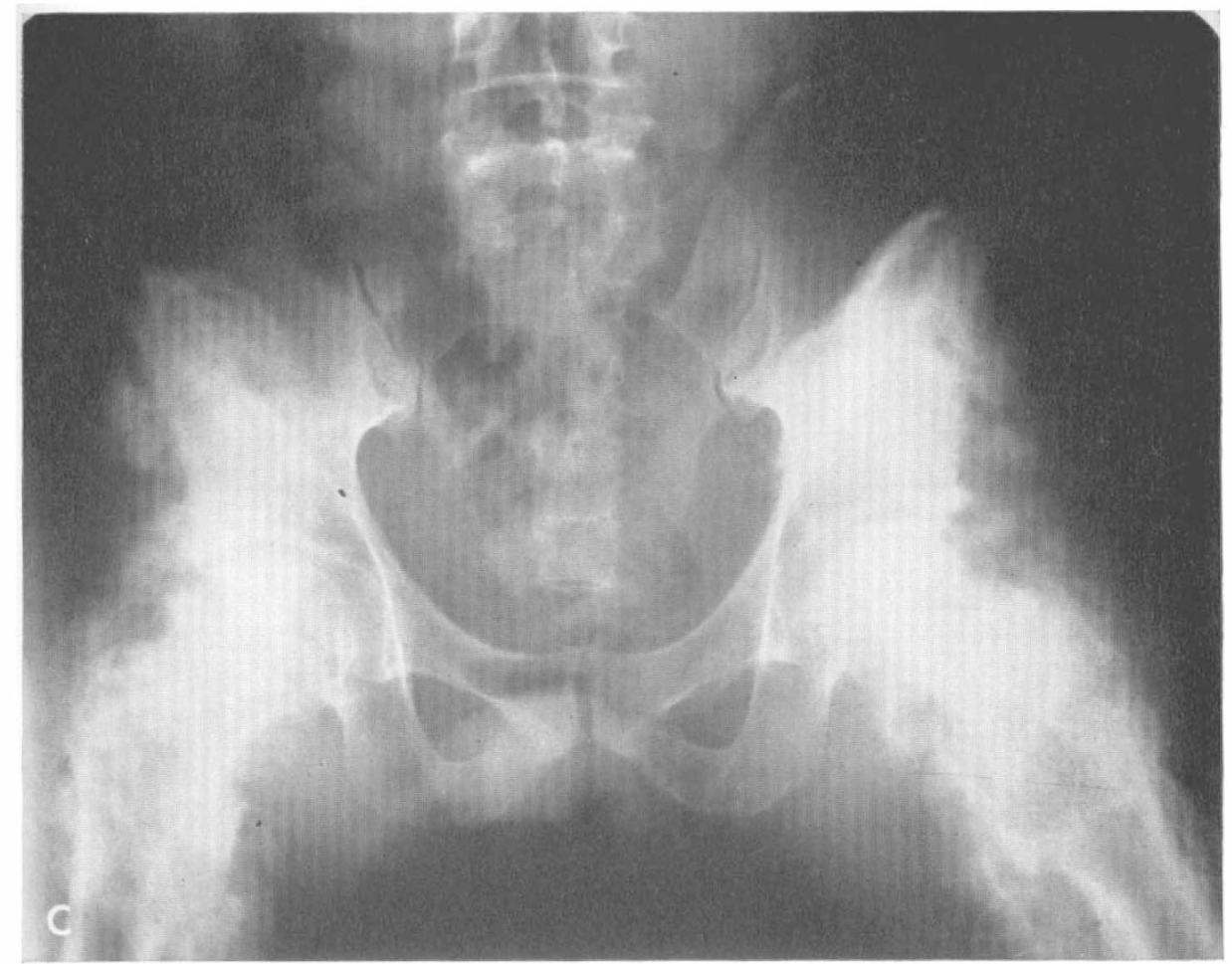

FIG. I

Sequence of films in Case 3, showing progression of disease despite treatment with edathamil. Fig. I $a$-five months before treatment. Fig. I $b$-one month before treatment. Fig. I $c$-immediately after treatment.

studies should indicate the constancy of alkaline phosphatase elevation in these maladies and the reproducibility and cause of the observed decrease of alkaline phosphatase concomitant with disodium edetate therapy. We do not anticipate that similar attempts to produce improvement of clinical signs by means of a three-week course of intravenously administered disodium edetate will be more successful than that reported here.

It is possible, however, that through greater understanding of the pathologic process, perhaps earlier detection by means of screening procedures such as roentgen study of the pelvis, and by modifications of this therapy, such as lengthening the course of treatment and oral administration of the drug, more beneficial results may be achieved.

\section{SUMMARY AND CONCLUSIONS}

Periarticular calcification of three paraplegic patients was treated by the intravenous administration of disodium ethylenediamine tetra-acetic acid (disodium edetate), $50 \mathrm{mg}$. per kilogram of body weight, for a total of 15 days each. No clinical improvement by any criterion resulted. An effective treatment has yet to be described. 


\section{RÉSUMÉ}

L'auteur a éssayé de traiter les ostéomes para-articulaires chez trois paraplégiques, par injection intraveineuse d'édédate sodique ( 50 milligrammes per kilogramme de poids) en trois series d'injections de cinq jours chacune. Aucune ammélioration, tant sur le plan clinique que radiologique n'a été observée. Aucun traitement efficace n'a été encore décrit jusqu'a présent.

\section{ZUSAMMENFASSUNG}

Drei Querschnittsgelähmte mit periartikulären Verkalkungen wurden mit intravenösen Injectionen von Disodium Ethylene-Diamide tetra-acetic Acid (Disodium acetate) $50 \mathrm{mg}$ pro Kilo Körpergewicht, fünfzehn Tage lang behandelt. Dies war in jeder Beziehung erfolglos. Eine wirksame Behandlungmethode، liegt noch in der Zukunft.

\section{REFERENCES}

Clarke, N. E., Clarke, C. N., \& Mosher, R. E. (I955). Amer. F. med. Sci., 229, I 42. DAMANSKI, M. (I96I). F. Bone $\mathfrak{f} t$ Surg., 43B, 286.

Déjerine, Mme, \& Ceillier, A. (I9I8). Ann. Méd., 5, 497.

Dudley, H. R., Ritchie, A. C., Schilling, A., \& BAKeR, W. H. (1955). New Engl. $\mathcal{F}$. Med., 252, 33 I.

Foreman, H., Finnegan, C., \& Lushbaugh, C. C. (1956). F. Amer. med. Ass., r6o, 1042. Miller, L. F., \& O’Neill, C. J. (1949). F. Bone ft Surg., 31A, 283.

\section{DisCUSSION}

Grossiord, A. (France) had made studies with radio-active calcium and referred to a patient who was just developing para-articular ossifications.

Michaelis, L. S. (England): In order to clarify biochemical findings on para-articular calcification, it was important to classify these in three groups: (I) Ectopic calcifications after trauma. These may be the result of haematoma which calcifies. (2) Ectopic calcification around osteomyelitic bone as the result of pressure sores. (3) The group about which Dr. Mead had just spoken. He also referred to the surgical treatment in para-articular calcifications. He mentioned four patients who had benefited from excision of the ossified mass around the hip joint. 